J. Japan. Soc. Hort. Sci. 58(1) : 1-8. 1989.

\title{
Relation between Early Drop of Apple Fruit and Ethylene Evolution under High Night-Temperature Conditions
}

\author{
Satoru KONDO and Yuji TAKAHASHI \\ Kazuno Branch, Akita Fruit Tree Experiment Station, Kazuno, Akita 018-52
}

\begin{abstract}
Summary
The present report aims to analyze the mechanism of fruit abscission under high night-temperature (HNT) conditions which promote the abscission.

The relationship between the rate of fruit abscission and ethylene evolution was investigated for the apple cultivars Tsugaru, Starking Delicious (SD) and Fuji. The rate of fruit abscisson of 'SD' was the highest, followed by that of 'Tsugaru' and then 'Fuji'. Ethylene evolution from these fruits also showed a similar trend.

Application of $100 \mathrm{ppm}$ ethephon gradually increased the rate of seed abortion and fruit abscission with time after treatment. Aminoethoxy-vinylglycine (AVG) application prevented ethylene evolution and reduced the rate of seed abortion, fruit abscission and cellulase activity in the abscission zone.

Based on these results, it is concluded that the increase in endogenous ethylene levels of fruit prevented seed development and caused fruit abscission under HNT treatment, and that the most susceptible cultivars were the ones in which ethylene evolution was the highest.
\end{abstract}

\section{Introduction}

In a previous report (19) it was demonstrated that early fruit drop of apple was promoted by high night temperatures (HNT), and that the rate of fruit abscission was reduced by over 60 $\%$ in comparison with the control by the inhibition of ethylene production in the fruit.

Walsh et al. (27) and Williams (30) showed that a high level of endogenous ethylene was associated with fruit abscission. In addition, studies have been conducted to determine whether ethephon (2-chloroethylphosphonic acid), an ethylene releasing chemical, could be utilized as a fruit thinning agent $(16,17,24,27$, $32)$. Although a large number of reports (5, $6,7,10,31,34)$ have indicated that ethylene promotes fruit abscission, there have been only a few studies on how HNT affect the young fruit before abscission cccurs.

The purpose of this report is to analyze the mechanism of fruit abscission under HNT conditions.

\section{Materials and Methods}

Experiment 1. Rate of fruit abscission and Received for publication February 18, 1987. ethylene evolution in the apple cultivars Tsugaru, Starking Delicious and Fuji

Three 8- to 11-year-old trees of the apple cultivars Tsugaru, Starking Delicious(SD) and Fuji grafted on M. 26 rootstocks were selected in 1983-1986, respectively. Flowers in the center of a cluster, which were hand-pollinated with the pollen of 'Ohrin' in full bloom, were used in the experiment. The 150 fruits which had grown uniformly were marked 1015 days after full bloom(AFB), and the number of fruits remaining on the trees was recorded at intervals of $3-5$ days until early July when fruit abscission ceased.

The fruits were collected for ethylene analysis at intervals of 3-5 days from May 28 (15 days AFB) to July 3 (51 days AFB) in 1985 . Ethylene evolution from fruit was determined by gas-chromatography (FID) as described in the previous report (19).

Experiment 2. Effects of $A V G$ and ethephon application on the formation of the abscission layer of the peduncle, cellulase activity in the abscission zone and seed degeneration

Four 9-year-old 'SD' apple trees grafted on M. 26 rootstocks were selected in 1986. In the experiment on the effect of AVG application, 
apple trees were enclosed in a pipe-frame greenhouse covered with a $0.1 \mathrm{~mm}$ clear polyvinyl chloride film and heated during the night $(6.00 \mathrm{pm}$ to $6.00 \mathrm{am})$ by a warm-air heating apparatus with a thermostat. The temperature treatments were continued as follows; (A): for 4 days from June 9 (23 days AFB), after 500 ppm AVG solution containing 0.01\% wetting agent (Suntokten, Yamamoto Nohyaku Co., Ltd.) was hand-sprayed on only the fruits on June 7, (B) : for 7 days from June 16 (30 days $\mathrm{AFB})$, after $500 \mathrm{ppm}$ AVG solution mixed with $0.01 \%$ wetting agent (Suntokten) was sprayed on only the fruits on June 12. Thereafter, the apple trees were sprayed with a 100 ppm ethephon solution(C) on June 8 (23 days $\mathrm{AFB}$ ) or a $300 \mathrm{ppm}$ solution(D) on June 18 (32 days AFB).

Fifty fruits, which had grown uniformly, were marked for each of the 4 treatments. The number of fruits remaining on the trees was recorded in the same way as in Exp. 1. In addition, the effects of these treatments on the rate of seed abortion and cellulase activity in the abscission zone were also examined.

For these investigations, representative fruits which had grown uniformly in each treatment were collected, and the seeds with withered and browned inner parts were scored as having aborted.
Furthermore, the junction between the peduncle and bourse was fixed with F.A.A., dehydrated in an n-butyl alcohol series, embedded in paraffin and cut into $15 \mu \mathrm{m}$ thick longitudinal sections prior to staining (hematoxylin solution). Cellulase activity was determined according to the method of Iwahori and Oohata (15). Hence, $2 \mathrm{~mm}$ sections including the abscission zone between the peduncle and bourse were cut, and $1 \mathrm{~g}$ of tissue homogenized in 5 $\mathrm{ml}$ of $67 \mathrm{mM}$ phosphate buffer ( $\mathrm{pH} \mathrm{7)}$ containing $100 \mathrm{mg}$ polyclar AT and $5 \mathrm{mg}$ sodium Lascorbate, and then centrifuged. The procedures described above were carried out at $0-1$ ${ }^{\circ} \mathrm{C}$. The reaction mixture, containing $2 \mathrm{ml}$ of the supernatant (enzyme) solution and $4 \mathrm{ml}$ of a $0.8 \%$ carboxy methylcellulose (CMC) solution, was placed into an Ostwald viscosity meter and then incubated for $20 \mathrm{hr}$ at $30^{\circ} \mathrm{C}$.

\section{Results}

Exp. 1. Rate of fruit abscission and ethylene evolution in the apple cultivars Tsugaru, Starking Delicious and Fuji

Fig. 1 shows the rate of abscission of the fruits of the 3 cultivars between 1983-1986.

The rate of fruit abscission of 'SD' was the highest followed by that of 'Tsugaru', while that of 'Fuji' was the lowest throughout the 4 year period. In particular, 'Fuji' fruits did not

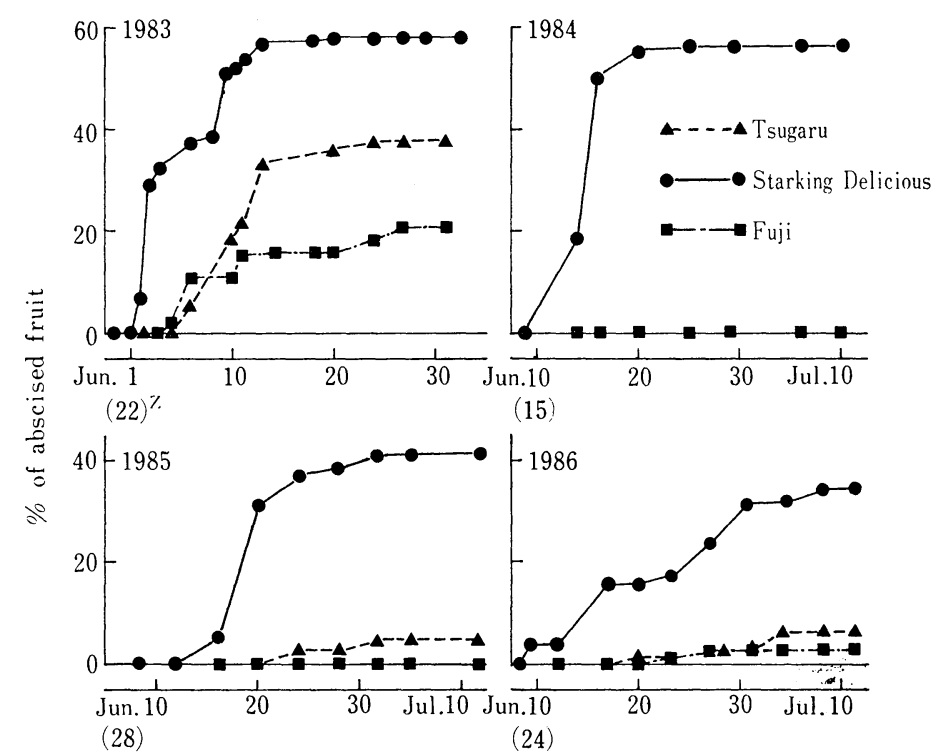

Fig. 1. Rate of early fruit drop of apple cultivars Tsugaru, Starking Delicious and Fuji in 1983-1986.

z Days after full bloom. 


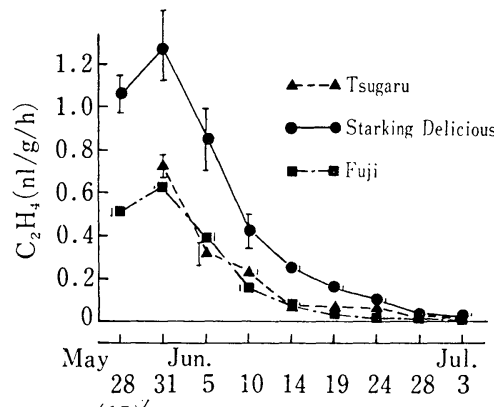

$(15)^{\prime}$

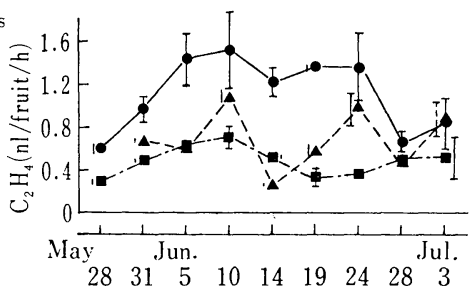

(15)

Fig. 2. Ethylene evolution from young fruits of the apple cultivars Tsugaru, Starking Delicious and Fuji (1985).

$\mathrm{z}$ As in Fig. 1. Vertical bars indicate S. E..

display abscission in 1984 and 1985.

Fig. 2 shows the evolution of ethylene from these cultivars. Ethylene evolution per gram fruit weight in 'SD' was 2-8 times higher than that in the other two cultivars during the period from 15 to 51 days AFB. Moreover, ethylene evolution per fruit was also the highest in 'SD', followed by 'Tsugaru' and then 'Fuji' as shown in Fig. 2.

Exp. 2. Effects of $A V G$ and ethephon appli-

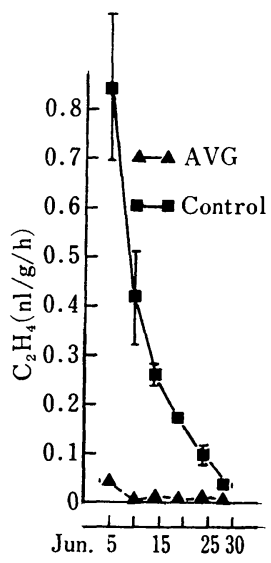

$(23)^{\mathrm{Z}}$

Fig. 3. Effect of AVG application on ethylene evolution from fruit (1985).

$\angle$ As in Fig. 1. Vertical bars indicate S. E..

AVG solution (500 ppm) was applied on June 3. cation on the formation of the abscission layer of the peduncle, cellulase activity in the abscission zone and seed degeneration

Figs. 3 and 4 show the effects of the application of $500 \mathrm{ppm}$ AVG on ethylene evolution from fruit, fruit abscission and cellulase activity in the abscission zone. AVG application inhibited ethylene evolution from 50 to $5 \%$ for 25 days after the spray compared with the untreated control (Fig. 3).

In the HNT treatment applied on June 9 ( 23 days $\mathrm{AFB}$ ), the mean temperature vas 19.2$20.9{ }^{\circ} \mathrm{C}$ as shown in Table 1 . The abscission rate of the fruits sprayed with AVG was only $8.0 \%$, whereas that of untreated fruits was $50.0 \%$. Cellulase activity in the abscisson zone of fruits sprayed with AVG was lower than that of untreated fruits on both June 13 and 19 (6 and 12 days after the spray, respectively) (Fig. 4A). In the HNT treatment applied on June 16 (30 days AFB), the mean temperature was $20.2-23.7^{\circ} \mathrm{C}$ (Table 1 ). The abscission rate of the fruits sprayed with AVG was 26.0 $\%$, and that of untreated fruits amounted to $90.0 \%$. The cellulase activity in the abscission zone on June 23 (11 days after the spray) of the fruits sprayed with AVG was lower than that of untreated fruits (Fig. 4B).

Figs. 5 and 6 show the effect of ethephon

Table 1. Mean temperature during the high night-temperature (HNT) treatment (1986).

\begin{tabular}{|c|c|c|c|c|c|c|c|c|c|c|c|}
\hline \multirow{3}{*}{ Treatment } & \multicolumn{11}{|c|}{ Mean temperature $\left({ }^{\circ} \mathrm{C}\right)(6.00 \mathrm{pm}$ to $6.00 \mathrm{am})$} \\
\hline & \multicolumn{4}{|c|}{$\mathrm{A}$} & \multicolumn{7}{|c|}{$\mathrm{B}$} \\
\hline & June 9 & 10 & 11 & 12 & June 16 & 17 & 18 & 19 & 20 & 21 & 22 \\
\hline HNT & 20.9 & 19.8 & 19.2 & 19.7 & 21.8 & 23.7 & 22.1 & 21.3 & 20.2 & 21.4 & 22.3 \\
\hline Outdoors & 15.5 & 14.5 & 13.6 & 14.3 & 19.2 & 19.0 & 17.5 & 16.3 & 14.1 & 16.0 & 16.4 \\
\hline
\end{tabular}




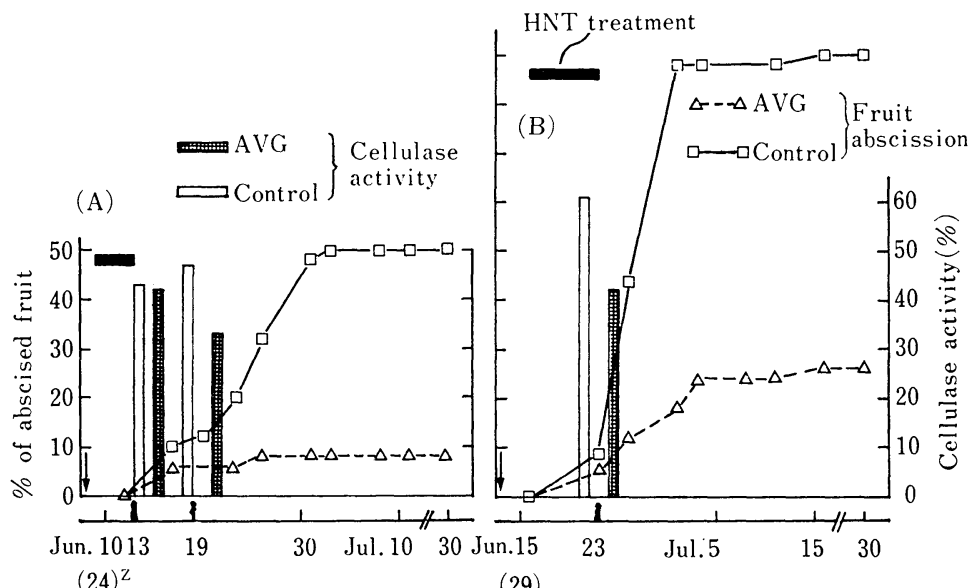

$(24)^{\mathrm{Z}}$

(29)

Fig. 4. Effect of AVG application on the rate of fruit abscission and cellulase activity in the abscission zone (1986).

$\mathrm{z}$ As in Fig. 1. HNT: High night temperature.

The arrow $(\downarrow)$ indicates the day when the AVG solution was sprayed.

Cellulase activity $(\%)=\frac{a-b}{a-c} \times 100 \quad \begin{aligned} & a \text { : flow time at the start of incubation } \\ & b: \text { flowe at the end of incubation }\end{aligned}$ $c$ : flow time of buffer solution

(A)

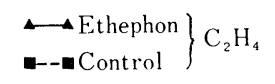

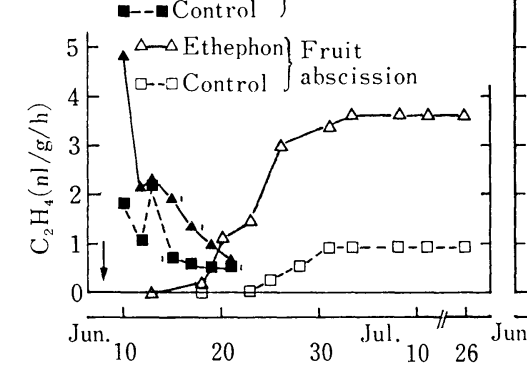

$(24)^{\mathrm{Z}}$
(B)

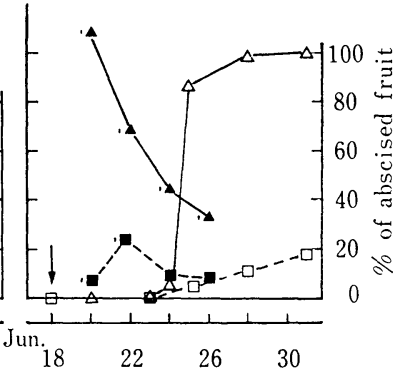

(32)

Fig. 5. Effect of ethephon application on the rate of fruit abscission and ethylene evolution from fruit (1986).

$\mathrm{z}$ As in Fig. 1. Vertical bars indicate S. E..

The arrow $(\downarrow)$ indicates the day when the ethephon solution was sprayed.

(A)

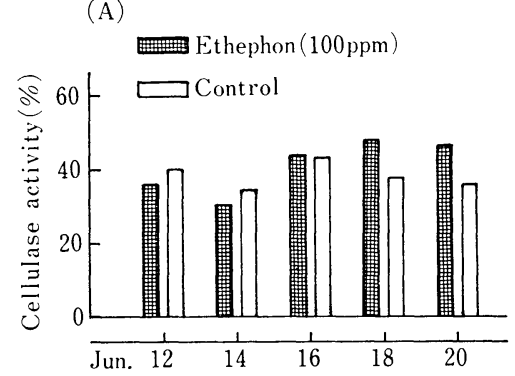

$(26)^{2}$
(13)

Ethephon (300ppm)

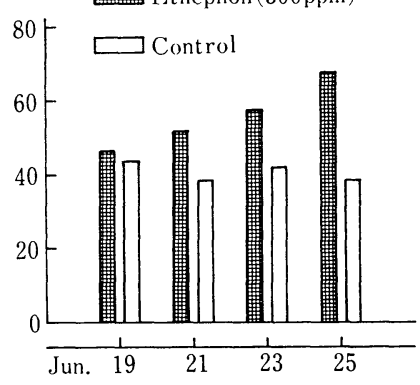

(33)

Fig. 6. Effect of ethephon application on cellulase activity in the abscission zone (1986).

$\mathrm{z}$ As in Fig. 1.

Ethephon was sprayed on June $8(100 \mathrm{ppm})$ and June 18 (300 ppm), respective)y. 
application on ethylene evolution, fruit abscission and cellulase activity in the abscission zone. Ethephon application markedly increased ethylene evolution from the fruits. The fruits sprayed with $100 \mathrm{ppm}$ ethephon on June 8 (22 days AFB) underwent gradual abscission from 9 days after application, and the final rate of fruit abscission amounted to $72.0 \%$ compared with $18.0 \%$ in the untreated control (Fig. 5A). The cellulase activity in the abscission zone of fruits treated with $100 \mathrm{ppm}$ ethephon, which until June 16 ( 8 days after the spray) hardly differed from that in which ethephon had been omitted, increased on and after June 18 (Fig. $6 \mathrm{~A})$. Over $80 \%$ of the fruits sprayed with $300 \mathrm{ppm}$ ethephon on Iune 18 (32 days AFB) experienced abrupt fruit abscission 6-7 days after the application, and all fruits subsequently dropped (Fig. 5B). The cellulase activity in the abscission zone of the fruits treated with $300 \mathrm{ppm}$ ethephon increased markedly on June 21 ( 3 days after the spary) (Fig. 6B). Thus, the effect of the concentration of the compound was conspicuous when sprayed on either date.

The cells in the abscission layer identified at the junction between the peduncle and bourse were smaller than the surrounding parenchyma cells. The thickness of the abscisson layer was about $100 \mu \mathrm{m}$ (Fig. 7).

Table 2 shows the effects of AVG and ethephon application on the rate of seed abortion. AVG application reduced the rate of seed abortion under both HNT treatments. The application of $100 \mathrm{ppm}$ ethphon increased the rate of seed abortion with time after application, whereas the application of $300 \mathrm{ppm}$ ethephon caused fruit abscission before seed development was influenced.

\section{Discussion}

Seed development is closely associated with early fruit drop at the young fruit stage (23). Weinbaum and Simons (28) also reported that the chemical thinning agents, NAA and Sevin, caused a reduction in seed size within 2 days of application while NAA caused a retardation in the development of all seed tissues. In Exp. 2 of this study, an application of $100 \mathrm{ppm}$ ethephon also enhanced seed abortion with time after the spray. As fruits which had grown uniformly were used for observation of seeds,

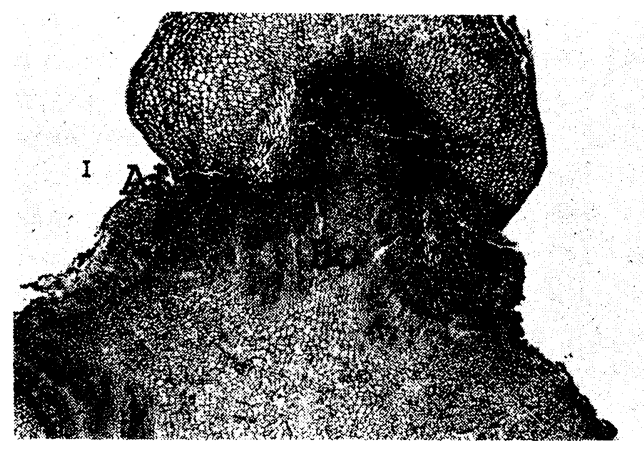

Fig. 7. Abscission layer formed at the junction between the peduncle and bourse of 'Starking Delicious' apple fruit (June 12 (26 days AFB), 1986). Pe: Peduncle. Bo: Bourse. AL: Abscission layer. Bar is $100 \mu \mathrm{m}$.

Table 2. Effects of ethephon and AVG application on the rate of seed abortion (1986).

\begin{tabular}{|c|c|c|c|c|}
\hline Treatment & $\begin{array}{l}\text { Jun. } 16 \\
(8)^{\mathrm{z}}\end{array}$ & $\begin{array}{c}\text { Jun. } 18 \\
\quad(10)\end{array}$ & $\begin{array}{c}\text { Jun. } 20 \\
\text { (12) }\end{array}$ & $\begin{array}{l}\text { Jun. } 26 \\
\text { (18) }\end{array}$ \\
\hline Ethephon $(A)^{y}$ & 9.6 & 25.7 & 28.9 & 57.1 \\
\hline Control & 6.7 & 9.6 & 15.2 & 7.7 \\
\hline Significance $^{x}$ & NS & $* *$ & NS & $* *$ \\
\hline Treatment & $\begin{array}{r}\text { Jun. } 19 \\
(1)\end{array}$ & $\begin{array}{l}\text { Jun. } 21 \\
\text { ( } 3 \text { ) }\end{array}$ & $\begin{array}{c}\text { Jun. } 23 \\
\text { ( } 5)\end{array}$ & $\begin{array}{l}\text { Jun. } 25 \\
(7)\end{array}$ \\
\hline Ethephon (B) ${ }^{\mathrm{w}}$ & 16.2 & 7.4 & 6.6 & 13.6 \\
\hline Control & 7.3 & 1.3 & 8.0 & 8.0 \\
\hline Significance & NS & NS & NS & NS \\
\hline Treatment & & $\begin{array}{c}\text { Jun. } 19 \\
\text { (12) }\end{array}$ & & $\begin{array}{r}\text { Jun. } 23 \\
\text { (11) }\end{array}$ \\
\hline $\operatorname{AVG}(a)^{v}$ & & 14.4 & & - \\
\hline Control (a) & & 37.7 & & - \\
\hline $\operatorname{AVG}(b)^{\mathrm{u}}$ & & - & & 6.7 \\
\hline Control (b) & & - & & 24.1 \\
\hline Significance & & $* * *$ & & $* *$ \\
\hline \multicolumn{5}{|c|}{$\begin{array}{l}\text { The number in the parenthesis indicates the days } \\
\text { after spray. } \\
\text { y Ethephon solution ( } 100 \mathrm{ppm} \text { ) was applied on June } \\
8 \text { ( } 22 \text { days AFB). } \\
\times \text { Significant at the student's t-test (** } 1 \% \text {, *** } 0.1 \\
\% \text { ) and not significant (NS) at } 5 \% \text { level. } \\
\text { w Ethephon solution ( } 300 \mathrm{ppm} \text { ) was applied on June } \\
18 \text { ( } 32 \text { days AFB). } \\
\text { AVG solution ( } 500 \mathrm{ppm} \text { ) was applied on June } 7 \\
\text { ( } 22 \text { days AFB) and then HNT treatment (a) was } \\
\text { continued from June } 9 \text { to } 13 \text {. } \\
\text { AVG solution ( } 500 \mathrm{ppm} \text { ) was applied on June } 12 \\
\text { (27 days AFB) and then HNT treatment (b) was } \\
\text { continued from June } 16 \text { to } 23 \text {. } \\
\text { Each value represents the mean of } 10 \text { fruits ( } 5 \text { repli- } \\
\text { cations). }\end{array}$} \\
\hline
\end{tabular}


it was considered that seed abortion occurred before fruit development had ceased. In contrast, it appears that the application of $300 \mathrm{ppm}$ ethephon abruptly increased the cellulase activity in the abscission zone before seed development was affected and resulted in fruit abscission. It was shown that cellulase was localized in the separation layer of the abscission zone (1), its activity increased before and during abscission and that it was closely associated with fruit abscission $(3,12,13,14,33,36)$. On this point, our current results also support these reports.

It has been shown that ethephon is broken down to form ethylene by a simple base-catalyzed reaction at $\mathrm{pH} 3.5$ and higher (3), and that it stimulates endogenous ethylene production $(26,34)$. Regarding the effects of ethylene application, Beyer $(4,5)$ demonstrated that the flow of auxin out of the leaf blade was reduced, Pallus and Kays (25) showed that net photosynthesis was inhibited, while Weinbaum and Muraoka (29) and Krewer et al. (20) reported that the translocation of photosynthates from the leaf into the fruit was retarded.

Ebert and Bangerth (11) reported that ethylene evolution was high at the younger stage of 'King of the Pippins' and 'Golden Delicious' apple fruits. The three cultivars in the current experiments also showed similar characteristics with ethylene evolution of 'SD' per fruit weight being the highest.

The abscission of fruit and leaf is affected by environmental factors $(18,22)$, and in a previous report (19) it was demonstrated that a high temperature of $25^{\circ} \mathrm{C}$ increased endogenous ethylene evolution from young fruits.

Therefore, it is considered that the young fruits of 'SD', in which ethylene evolution was higher than in the 'Tsugaru' and 'Fuji' fruits, were affected significantly by the increased amounts of endogenous ethylene when the fruits were subjected to HNT treatment, as well as to the application of ethephon at low concentrations. Hence, the translocation of hormone-like substances to the fruits was inhibited $(4,5)$ and, due to the reduction in the amount of photosynthates translocated to the fruits $(20,25,29)$, seed development was retarded. As a result, the amount of endogenous growth regulators $(2,21,23)$ produced in the seed was reduced, leading to the formation of the abscission layer and eventually resulting in fruit abscission. This phenomenon may also account for the fact that fruit abscission of 'Fuji' was hardly observed under HNT conditions(18), and that the application of AVG, an inhibitor of ethylene biosynthesis (35), reduced the rate of seed abortion and fruit abscission due to the decreased levels of endogenous ethylene in the fruits. Although the effect of AVG application was investigated under HNT conditions which promoted fruit abscission, a reduction of fruit abscission by AVG application under natural environmental conditions has also been reported by Child and Williams (8) and Williams (30). In these cases where AVG was sprayed on the whole tree including leaves, branches and fruits, the reduction in fruit abscission was affected by the regulation of vegetative growth (9), as well as the reduction in ethylene evolution. However, in the current studies, the rate of fruit abscission could be reduced even when only fruits were sprayed with AVG. Thus, it was shown that fruit abscission under HNT conditions was due to the fact that ethylene evolution from fruit prevented seed development, while the inhibition of ethylene evolution led to a reduced rate of fruit abscission under such conditions. However, the inhibition of ethylene evolution hardly reduced the rate of fruit abscission under shading (19), and $\mathrm{Na}$ kagawa et al. (23) showed that in peach the application of gibberellin was effective in promoting fruit set and development after the embryo had been destroyed. Therefore, it is assumed that other growth regulators such as auxins, gibberellins and cytokinins in the seeds play an important role in fruit development, as will be presented in a subsequent report.

\section{Acknowledgements}

We are grateful to Prof. C. Oogaki at Tsukuba Univ. for his critical reading of this manuscript, and to Dr. T. Yamazaki, Fruit Tree Res. Stn. for his helpful suggestions. We thank Mr. O. Kotoh from Nippon Roche who provided AVG.

\section{Literature Cited}

1. Abeles, F. B. 1969. Abscission: role of cellulase. Plant Physiol. $44: 447-452$.

2. Abeles, F.B., G. R. Leather, L. E. For 
RENCE and L. E. CRAKER. 1971. Abscission: regulation of senescence, protein synthesis, and enzyme secretion by ethylene. HortScience 6 : $371-376$.

3. Abeles, F. B. 1973. Ethylene in plant biology. Academic Press, New York.

4. Beyer, E.M., JR. and P.W. MORGAN, 1971. Abscission: the role of ethylene modification of auxin transport. Plant Physiol. 48:208212.

5. BEYER, E. M., JR. 1975. Abscission: the initial effect of etylene is in the leaf blade. Plant Physiol. 55 : 322-327.

6. BEYER, E. M., JR. 1976. Silver ion: a potent antiethylene agent in cucumber and tomato. HortScience 11 : 195-196.

7. BEYER, E. M., JR. 1976. A potent inhibitor of ethylene action in plants. Plant Physiol. 58 : 268-271.

8. CHILD, R. D. and R. R. Williams. 1983. The effects of the interaction of aminoethoxyvinylglycine(AVG) with mixtures of growth regulators on fruit set and shape in Cox's Orange Pippin apple. J. Hort. Sci. 58 : 365369.

9. Curry, E. A. and M. W. Williams. 1986. Physiological changes associated with increased lateral branching of apple trees treated with aminoethoxyvinylglycine. J. Amer. Soc. Hort. Sci. $111: 237-240$.

10. DEnNis, F. G., JR. 1970. Effects of gibberellins and naphthaleneacetic acid on fruit development in seedless apple clones. J. Amer. Soc. Hort. Sci. 95 : 125-128.

11. EBert, A. and F. BANGerth. 1985. Changes in the levels of phytohormones and possible relations to apple fruit development. I. Extractable IAA, GAs, ABA and ethylene. Gartenbauwissenschaft $50: 37-41$.

12. GOREN, R. and M. HUBERMAN. 1976. Effects of ethylene and $2,4-\mathrm{D}$ on the activity of cellulase isoenzymes in abscission zones of the developing orange fruit. Physiol. Plant. 37 : $123-130$.

13. GreenberG, J., R. Goren and J. Riov. 1975. The role of cellulase and polygaracturonase in abscission of young and mature shamouti orange fruits. Physiol. Plant. 34:1-7.

14. Huberman, M. and R. Goren. 1979. Exoand endo- cellular cellulase and polygaracturonase in abscission zones of developing orange fruits. Physiol. Plant. 45 : 189-196.

15. IWAHORI, S. and J. T. OOHATA. 1976. Chemical thinning of 'Satsuma' mandarin (Citrus unshiu MARC.) fruit by 1-naphthaleneacetic acid: role of ethylene and cellulase. Scientia
Hort. 4: 167-174.

16. Jones, K. M. and T. B. KOEN. 1985. Temperature effects on ethephon thinning of apples. J. Hort. Sci. $60: 21-24$.

17. Koen, T. B. and K. M. Jones. 1985. A model of ethephon thinning of Golden Delicious apples. J. Hort. Sci. $60: 13-19$.

18. KONDO, S., M. ASARI and M. KuMAGAI. 1987. Effects of weather conditions, tree vigor, and pruning on the early fruit drop of apple. J. Japan. Soc. Hort. Sci. 55:415-421. (In Japanese with English summary)

19. KONDO, S. and Y. TAKAHASHI. 1987. Effects of high temperature in the nighttime and shading in the daytime on the early drop of apple fruit 'Starking Delicious'. J. Japan. Soc. Hort. Sci. $56: 142-150$.

20. KreWER, G.W., J.W. DANiell, D.C. Coston, G. A. Couvillon and S. J. KAYs. 1983. Transport of $\left({ }^{14} \mathrm{C}\right)$-photosynthate into young peach fruits in response to CGA-15281, an ethylene-releasing compound. HortScience 18 : 476-478.

21. LEOPOLD, A. C. 1971. Physiological processes involved in abscission. HortScience $6: 376$ 378.

22. Marousky, F. J. and B. K. HarbAUGH. 1979. Interactions of ethylene, temperature, light and $\mathrm{CO}_{2}$ on leaf and stipule abscission and chlorosis in philodendron scandens subsp. oxycardium. J. Amer. Soc. Hort. Sci. 104 : $876-880$.

23. NAKAgAwa, S., I. KiYOKAwa, H. Matsui and H. KUROOKA. 1973. Fruit develcipment of peach and Japanese pear as affected by destruction of the embryo and application of gibberellins. J. Japan. Soc. Hort. Sci. 42 : 104 -112 .

24. NAKAmURA, M. and S. WaKASUgi. 1978. Chemical thinning of Japanese persimmon trees using ethrel sprays. I. Influence of eth rel on the abscission layer formation of flower o $r$ fruit and its development. J. Japan. Soc. Hort. Sci. 47 : 308-316. (In Japanese with E.nglish summary).

25. PAllas, J. E., JR. and S. J. KAYS. 1982. Inhibition of photosynthesis by ethyl $\epsilon$ ne-a stomatal effect. Plant Physiol. 70 : 598-601.

26. RiOV, J. and S. F. YANG. 1982. Effects of exogenous ethylene on ethylene productjon in citrus leaf tissue. Plant Physiol. $70: 136-141$.

27. Walsh, C. S., H. J. SWartz and L. J. EDGERTON. 1979. Ethylene evolution in apple following post-bloom thinning sprays. HortScience 14:704-706.

28. Weinbaum, S. A. and R. K. Simons. 1974. 
Histochemical appraisal of the relationship of seed abortion to chemical induction of apple fruit abscission following bloom. J. Amer. Soc. Hort. Sci. $99: 266-269$.

29. Weinbaum, S. A. and T. T. MuraokA. 1978. Chemical thinning of prune: relation of assimilate deprivation to ethylene-mediated fruit abscission. HortScience $13: 159-160$.

30. Williams, M. W. 1981. Response of apple trees to aminoethoxyvinylglycine (AVG) with emphasis on apical dominance, fruit set, and mechanism of action of fruit thinning chemicals. Acta Hort. 120 : 137-141.

31. Wittenbach, V. A. and M. J. Bukovac. 1973. Cherry fruit abscission: effect of growth substances, metabolic inhibitors and environmental factors. J. Amer. Soc. Hort. Sci. 98 : $348-351$.

32. WOOD, B. W. 1983. Fruit thinning of pecan with ethephon. HortScience $18: 53-54$.

33. YAMAMURA, H., R. NAITO and K. MOCHIDA.
1976. Mechanism of the thinning action of NAA in Japanese persimmon (kaki) fruits. II. Effects of NAA applied at various stages of fruit growth on the induction of fruit drop and the activity of endogenous growth substances and some enzymes in fruit tissues. J. Japan. Soc. Hort. Sci. $45: 1-6$. (In Japanese with English summary)

34. YAMAMURA, H. and R. NAITO. 1980. Mechanism of the thinning action of NAA in Japanese persimmon (kaki) fruits. III. Effects of gibberellin application on NAA and ethephoninduced ethylene production and fruit drop. J. Japan. Soc. Hort. Sci. 49 : 171-179. (In Japanese with English summary)

35. YANG, S. F. 1985. Biosynthesis and action of ethylene. HortScience $20: 41-45$.

36. ZUR, A. and R. GOREN. 1977. Reducing preharvest drop of 'Temple' orange fruits by $2,4-\mathrm{D}$-role of cellulase in the calyx abscission zone. Scientia Hort. $7: 237-248$.

\title{
夜間高温条件下におけるリンゴの早期落果とエチレン発生との関係
}

\author{
近藤 悟 $\cdot$ 高橋佑治 \\ 秋田県果樹試験場鹿角分場 018-52 鹿角市花輪
}

\footnotetext{
摘 要

リンゴ・スターキング・デリシャス’の早期落果を誘 発する夜間高温下での落果機構を明らかにし，そのよう な気象条件下において落果を防止するための基礎的資料 を得ようとした。

‘つがる’、‘スターキング・デリシャス’及び ‘ふじ’ の 3 品種につき早期落果率とエチンン発生量とを調査し たところ，早期落果率は ‘スターキング・デリシャス’, ‘つがる’, ‘ふじ’の順们高く, 果実からのエチレン発生 量も同様となった。

エセフォン散布と夜間高温条件下での AVG（アミノ エトキシビニルグリシン）散布が, 種子の発育, 離層部

のセルラーゼ活性，落果率に及ぼす影響について調査し た. 低濃度 $(100 \mathrm{ppm})$ のエセフォン処理は散布後の日 数とともに種子の発育を阻害し，徐々に落果させた。一 一 方，AVG 散布は内生エチンンの発生を低下させ，さら に種子の発育阻害，セルラーゼ活性及び落果率を減少さ せた。

これらより，夜間高温のような温度が関与する条件下 では, 果実中の内生エチレンレベルの增加が種子発育を 阻害し落果をひきおこしたと思われ，エチレン発生量の 多い品種で落果率の高かったことと関連すると思われ た。
} 